\title{
The Effect of Using Jigsaw Cooperative Learning Technique in Teaching Computer Literacy on Students' Achievement and Retention
}

\author{
Mehmet TEKDAL $^{a^{*}}$, Seval SÖNMEZ ${ }^{b}$
}

${ }^{a}$ Çukurova Üniversitesi, Eğitim Falültesi, Adana/Türkiye

b24 Kasım İlköğretim Okulu, Adana/Türkiye

\section{Article Info}

DOI: $10.14812 /$ cufej.398633

Article history:

Received 26.02.2018

Revised 23.03.2018

Accepted 03.04.2018

Keywords:

Cooperative Learning,

Computer Literacy,

Jigsaw Technique,

Academic Achievement.

\begin{abstract}
The main purpose of this empirical study was to investigate the effect of using jigsaw technique of cooperative learning method on sixth grade students' achievement in teaching computer literacy lesson. Fifty five sixth grade students from two class of a public school in Turkey participated in this study. With a quasi-experimental pretestpost-test research design, one class assign to experimental and the other to control group randomly. While the experimental group $(n=33)$ instructed with jigsaw technique of cooperative learning method, the control group $(n=22)$ followed the regular curriculum with traditional instructional methods. Both groups were administered to an achievement test, as pre, post and retention test. A t-test analysis was used to analyses research data. The results of post-test indicated that students in experimental group had significantly higher achievement scores than students in the control group. However, no significant difference found between the groups on retention test scores.
\end{abstract}

\section{İşbirliğine Dayalı Öğrenme Yöntemi, Birleştirme Tekniği ile Bilgisayar Okur-yazarlığı Öğretiminin Akademik Başarıya ve Kalıcılığa Etkisi}

\begin{tabular}{|c|c|}
\hline \multicolumn{2}{|c|}{ Makale Bilgisi } \\
\hline \multicolumn{2}{|c|}{ DOI: 10.14812/cufej.398633 } \\
\hline \multicolumn{2}{|c|}{ Makale Geçmişi: } \\
\hline Geliş & 26.02 .2018 \\
\hline Düzeltme & 23.03 .2018 \\
\hline Kabul & 03.04 .2018 \\
\hline \multicolumn{2}{|c|}{$\begin{array}{l}\text { Anahtar Kelimeler: } \\
\text { İşbirliğine Dayalı Öğrenme, } \\
\text { Bilgisayar Okur-Yazarlığı, } \\
\text { Birleştirme Tekniği, } \\
\text { Akademik Başarı. }\end{array}$} \\
\hline
\end{tabular}

\section{Öz}

\begin{abstract}
$\mathrm{Bu}$ deneysel çalışmanın temel amacı, 6. Sınıf bilgisayar okur-yazarlığı dersinin öğretiminde işbirlikli öğrenme yöntemi birleştirme tekniği kullanmanın etkisini araştırmaktır. Bu çalışma Türkiye'de bir devlet okulunun rastgele seçilen iki sınıfındaki elli beş altıncı sınıf öğrencisi ile yapılmıştır. Bu yarı deneysel ön test-son test desenli araştırmada bir sınıf deney, diğeri kontrol grubuna rastgele atanmıştır. Deney grubu ( $n=33$ ), ile işbirlikli öğrenme yöntemi birleştirme tekniği ile öğretim yapılırken, kontrol grubu $(n=22)$ ile süregelen öğretim programını geleneksel öğretim yöntemleriyle ders işlendi. Her iki grup, ön, son ve kalıcılık başarı testine tabi tutuldu. Araştırma verilerini analiz etmek için t-testi analizi kullanılmıştır. Deney sonrası test sonuçları, deney grubundaki öğrencilerin başarı puanları ile kontrol grubundaki öğrencilerin puanları arasında, deney grubu lehine anlamlı farklılık olduğunu gösterdi. Bununla birlikte, kalıcılık testi puanları dikkate alındığında grupların puanları arasında anlamlı bir fark bulunmamıştır.
\end{abstract}

\section{Introduction}

In order for instructional activities to provide the desired learning, appropriate methods and techniques must be used. It is unlikely that a teaching method will be efficient for each course. The teachers should know and use different teaching methods and techniques according to the speed and level of learning of the students and the nature of the subject.

In computer literacy teaching, various methods and techniques are used for learning becomes easier and more effective based on the light of the researches carried out. However, in Turkey the inadequacy 
of the physical conditions of the public schools and the crowd of the classes obstruct the efficient use of teaching methods and techniques. For this reason, the methods to be used should be determined taking into consideration the conditions of the schools. Especially the crowded classes cause computers to be inadequate in computer laboratories. In laboratories there are 3-4 students per computer. Therefore, applying the methods that students will learn by working together will make learning more efficient and effective.

\section{Objective}

In this study, the effect of using jigsaw cooperative learning technique in teaching computer literacy on students' achievement and retention was investigated. Based on this objective, research questions formulated as below:

1. Is there a significant difference between students in experimental and control groups in terms of academic achievement?

2. Is there a significant difference between students in experimental and control groups in terms of retention?

\section{Importance}

In literature review studies, it has been found that there are many researches in classes of different levels and subjects with using cooperative learning methods. For example, changes in shape and molecular solubility from physical changes, and acid-base reactions, combustion reactions and changes depending on heating from chemical changes (Tarhan, et al. 2013), ethnic integration and sustainable development (Olukayode \& Salako, 2014), vocabulary knowledge and active-passive voice in English as a foreign language for engineering students (Gömleksiz, 2007), the effect of written expression (Şahin, 2011), on students self-efficacy and achievement in chemistry (Mari \& Gumel, 2015), students' instructional quality on the academic performance (Berger \& Hänze, 2015), in the college English class (Mengduo \& Xiaoling, 2010), teaching chemical bonding at tertiary level (Doymus, 2008), teaching fractions and measurement Artut \& Tarim, 2007) and in economics education (Wyk, 2012). However, much research has not been done on the use of the jigsaw collaborative learning technique in teaching Computer Literacy subject. Based on this research, the effectiveness of jigsaw technique of collaborative learning method was evaluated in Computer Literacy lesson. It is thought that this research will benefit the following issues:

1. To provide scientific data in the selection of the methods to be used in computer literacy teaching process.

2. It is aimed to help the cooperative learning method to educate more qualified individuals who can communicate with each other, share what they know, know how to feel confident and work together.

3. To shed light on teachers who teaching computer literacy in primary schools, to offer new ideas on how to perform more efficient and effective teaching, and then to shed light on studies on computer literacy teaching.

\section{Assumptions}

The following assumptions were adopted in this study;

1. It was assumed that students are asked to answer the tests correctly and sincerely.

2. It is assumed that the effect of uncontrolled variables are the same for both of the experimental and control groups.

3. It is assumed that views of expertise on the scope validity of the prepared achievement tests are sufficient. 


\section{Limitations}

This research is limited to:

1. A public elementary school with 6th grade students.

2. A computer course with a unit.

3. The laboratory conditions of the school.

4. The Jigsaw Cooperative Learning Technique.

\section{Theoretical Background and Literature Review}

\section{Cooperative learning}

Cooperative learning is defined as "an interactive learning-teaching method based on the principle of working together in small groups of students (2-4 persons) in a business unit to maximize the common learning objectives" (Johnson, \& Smith, 1999).

Contemporary education concept has imposed on teachers the obligation and responsibility to implement the teaching method to be realized at the maximum level of learning. However, the majority of teachers use the traditional method of teaching which is based on the textbooks specified (with the influence of existing curriculum programs) and the participation of students as passive listeners. Some teachers are known to use the printing (dictation) method, believing that students are actively involved. In spite of these classical methods that learning and teaching take place at a certain level, the research shows that these methods are far from meaningful and efficient for many students. Lazarowitz criticizes the teacher-narrated method of expression as merely encouraging hard-working students, encouraging them to learn through individual work and competition, and insisting that all students in the class have not contributed sufficiently to the academic and social development of the classroom, suggesting that teachers use other methods. According to Lazarowitz (1995), the narrative method has many disadvantages especially for students with comprehension difficulties, since they are not sufficiently suited to asking students to explain, discuss and understand their thoughts. Slavin (1990) emphasizes that a satisfying educational environment should be an environment in which learners are mentally active participants, internalized by passing knowledge through the mind, ideas can be assembled and tested.He also stated that the environments in which students can freely explain, discuss, and listen to each other freely in their individual thoughts make learning activities more effective, productive and speedy.

The Collaborative Learning Method is also an effective tool for problem solving and creative thinking. Unlike individual learning methods, this method is based on the principle that students work together to solve problems. So, solving a problem together, means generating more solution suggestions. The Brainstorming Method, one of the most effective tools of creative thinking, is also a strategy that needs to work together.

In collaborative learning environment, small groups are used for educational purposes in order to enable students to personally work together towards a common goal of increasing their own learning and learning each other. Group members are different in terms of talent, personality traits, gender, academic achievement and social skills. So this method of learning can be successfully applied to each age group, course and subject area at all level.

Collaborative learning is similar to classical group work, but each group work is not cooperative learning. In order for a group study to be cooperative learning, the students in the group should try to maximize the learning of both themselves and the other members. In order for cooperative learning to take place, it is necessary for students in one group to interact and to cooperate with each other rather than to do some part of the work independently. According to Küçükahmet (1997), students simply forget what they hear, however, an educational activity they themselves attend helps them to understand better and not to forget easily. 
Collaborative learning is a method of learning that can be used in each age group,applied successfully in the teaching of each course and each level of subject area. There is a conviction that "the crowding of the classes makes it difficult to implement the method". However, the research shows that it also can be applied successfully in crowded classes (Steiner, Stromwall, Brzuzy \& Gerdes, 1999).

Generally two types of collaborative learning clusters can be created, structured and unstructured. Structured collaborative learning clusters are clusters of a certain number of learners, a well-defined topic that lasts from a few days to several weeks. Techniques can be defined for the specific subject area in which the stages of planning application and evaluation are already evident, and their implementation is based on techniques that require a certain period of time. On the other hand, unstructured collaborative learning clusters are provisionally created and used only until the end of a discussion or course (Holubec, Johnson, \& Johnson, 1993).

The foundations of the Jigsaw Technique, developed by Aronson (2002) and his colleagues, are based on the authors' long years of work in the areas of Group Dynamics and Social Interaction. It is one of the "pure" collaborative teaching techniques. In this technique, groups of 3-6 students are formed. Academic material (unit) divided into 3-6 divisions (subject). Each cluster is given the same unit and is asked to select one of the members of the cluster. Each member works on their own. Then members who have the same position in different clusters come together in 'clusters of expertise' and discuss on the subject. They then return to their group. The reunited group members are obliged to teach each other what they have prepared. They are given a certain amount of time for this, and at the end of this training they are told that they will come to the individual concerned about the subject. In the jigsaw technique, students have to listen to each other so that all of them can be learned. So, positive dependence is quite high. In addition, every student is both a teacher and a learner. This creates an environment where some students are prevented from dominance. Everyone's contribution in the group is valuable.

In this technique, students can learn other topics only by listening to their friends. Students are expected to show interest and support for the work of their other friends. After the students have finished teaching each other in the cluster, each student enters the unit exam individually. Individuals get points from this exam.

\section{Computer Literacy and Cooperative Learning}

In 21st century, one of the fundamental aims within primary education in Turkey, as it is in all other countries, is to provide an effective and efficient computer literacy learning environment where students learn effectively as a result of changes in the direction of globalization of primary education. The developments indicate that Computer Literacy in this century will come to an inevitable need for a contemporary human being. It is already clear that individuals who do not have this skill will not have the opportunity to find work, improve themselves, or contribute to production. So Literacy should now include basic computer skills (Orhan, 1995). For this reason, it is necessary to use more effective methods to teach computer literacy.

On the other hand, the traditional teaching methods which mostly teacher-centered, have always focused on the lecture-based methods in which the students are passive receiver of knowledge. However, in recent years there has been a remarkable shift towards student-centered teaching methods. When using cooperative learning method in learning environment, all students in the class actively participates to a task at the same time. In this way, students can argue and compare their findings (Yang and Cheung, 2003). So, cooperative learning method, which is among these modern learning methods, could be used in computer literacy classes effectively.

Cooperative learning, as mentioned above, is one of the most popular and productive areas of theory, research, and practice in education. This combination of theory, research, and practice makes cooperative learning one of the most distinguished of all instructional practices (Johnson, Johnson\&Stanne, 2000) and it generally refers to students working together to achieve the goals and the instructional procedures that build the students' collaborative efforts. The success of collaborative 
learning method in applied sciences is frequently found in literature studies. For example, in Biology (Haack, 2014), Physics (Gambari, \& Yusuf, 2016), Chemistry (Apugliese \& Lewis, 2017; Warfa, 2015), Mathematics (Capar \& Tarim, 2015; Alabekee, Samuel \& Osaat, 2015), Science and Technology(Altun, 2015), Computer Science(Othman, Hussain \& Nikman, 2017). Because, the computer literacy is mostly an applied science, it could be said that this nature of cooperative learning can play an important role in teaching computer literacy.

Computer literacy ranges from computer awareness to programming languages. The investigations emphasize the necessity of individuals having the ability to use computers as much as they need in daily life.So it is defined as education in order to acquire computer and basic concepts, develop skills to use in the direction of computer aim and expectation, and to acquire the habit of follow developments in the field of computer science (Keser \& Teker, 2011).

Computer literacy education aims to learn how to use computer technology to conduct research and gather information. Besides this, computer cultures, with texts, illustrations, games and interactive multimedia, see it as an area where new forms of literacy develop. Moreover, computer culture is a discursive and political field where learners, teachers and citizens converge through discussion groups, research projects, websites, multimedia and other forms of new learning and social interaction.

According to Aytaç (2000), expanded computer literacy; how to learn how to use the computer, how to access the information, training materials, e-mail and listing services and web site preparation. Computer literacy is the so-called information society, which involves the development and use of very different kinds of information. This also includes learning new ways of accessing information sources that have changed, such as in new internet web sites and search engines, instead of collaborative building (like libraries) and print media. Computer literacy also involves learning where to find information, how to get there, how to interpret it, and how to measure the value of information.

\section{Method}

In this section, method, research model, study group, experimental design, application, data collection tools, data collection process and analysis of data are explained.

\section{Research Model}

This study investigated the effectiveness of collaborative learning method in teaching computer literacy to 6 th grade primary school students. In a public primary school, sixth grade students who took computer courses were studied. Two groups, which randomly selected, were formed as experimental and control group. The Jigsaw Cooperative Learning method was administered to the experimental group and traditional methods and techniques (lecture, question-answer, demonstration, individual study and educational games) were administered to the control group. In order to determine the effects of the methods used on academic success and retention, 'Pretest-Posttest control group model' was used. The experimental design of the research model is shown in Table 1.

Table 1.

The Experimental Design of the Research Model.

\begin{tabular}{lcccc}
\hline Grups & Pretest & Teaching Method & Posttest & RetentionTest \\
\hline Experimental & $\mathrm{O}_{1.1}$ & $\mathrm{X}_{1}$ & $\mathrm{O}_{1.2}$ & $\mathrm{O}_{1.3}$ \\
Control & $\mathrm{O}_{2.1}$ & $\mathrm{X}_{2}$ & $\mathrm{O}_{2.2}$ & $\mathrm{O}_{2.3}$ \\
\hline $\mathrm{O}_{1.1}:$ Pretest of experimental group & & & \\
$\mathrm{O}_{2.1}:$ Pretest ofcontrol group & & \\
$\mathrm{X}_{1}:$ Collaborative Learning Method (Jigsaw Technique) & \\
$\mathrm{X}_{2}:$ Traditional Learning Method & & \\
$\mathrm{O}_{1.2}:$ Posttest of experimental group & & \\
$\mathrm{O}_{2.2}:$ Posttest ofcontrol group & &
\end{tabular}


$\mathrm{O}_{1.3}$ : Retention testof experimental group

$\mathrm{O}_{2.3}$ : Retention testofcontrol group

\section{Participants}

The participants of this study consisted of 6th grade students taking computer lessons in a public primary school in Adana city of Turkey. One of two randomly selected groups was designated as the experimental group and the other as the control group. There are 16 female and 17 male students in the experimental group and there are 11 female and 11 male students in the control group.

\section{Procedure}

The application was made under the close supervision of a computer teacher with 5 years of experience who graduated from the Department of Computer Education and Instructional Technology.

In this study, two groups, an experimental and a control group was studied. Before starting to experiment, a pretest administered to both experimental and control group students. In the control group of the study, the course was used in a continuous and continuous manner. This method, in which the teacher is more active, is called the "Traditional method".

Before the course, students are informed about how the course will be handled and the rules that must be followed during the course are explained. Students were allowed to ask questions during the course and use the computer lab in off-hours. The assessment of the students' achievement was carried out as a test administration twice in the middle and at the end of the semester.

For the experimental group, jigsaw techniques of collaborative learning method were applied.Within the experimental group of the study, 9 learning groups were established based on cooperative learning method each of them consisting of 3-4 students. While the groups were being created, the students were ranked from the highest average score to the lowest average score according to the pretest score. Groups were formed based on the cooperative group principle, i.e. groups were mixed by considering the gender and achievement.

Before starting the application:

1. Information about the procedure was explained to the students.

2. The tasks of the groups are explained, how the expertise groups are to be created and the work to be done in the expertise groups.

3. A sample newspaper clipping was shown to the students for the activity to cover all content to be learned.

4. The concepts of writing, font, color, pictures and images placed at different dimensions in the different dimensions, centered on the writing or written on the left or right are presented on the board and explained to the students.

5. Each group was informed by the students who were going to do the same work and the group members were asked to share the concepts in context.

6. The members of the group were informed about their duties and responsibilities towards the group alone.

The teaching of computer literacy with the jigsaw techniques of collaborative learning method has been carried out for 4 weeks and 2 hours per weekwith the following steps.

1. Sharing of Content:First of all, learning groups based on cooperative learning consisting of 3 to 4 students were formed in the experimental group. Then, the concepts in the Standard and Format toolbars of Microsoft Word processing software were shared among the students and each student in the group was given a topic to share a part of the topic. For example, student \#2 
chooses to learn concepts such as Bold, Italic, Underline, Align left, Center, Align right, Justify, and examines other friends' selected topics.

2. Creating Expertise Groups: At this stage, the students were separated from their own groups and new groups were formed with students responsible for the same concept.These groups are called "expertise groups". In the specialist groups, students have tried to learn their subjects more clearly and have returned to their own groups.For example, one of these students works to learn the concepts they choose, then comes and joins the expertise group on their own to share their learning with their friends

3. In-group Teaching:The group members who were gathered again, taught what they learned to other friends in the group. The group members helped each other in collaboration to work together to help each member in the group learn all the concepts.

\section{Computer Literacy Achievement Test}

For this research, a 32-item multiple-choice computer literacy academic achievement test was prepared, covering goals and behaviors determined in terms of content and content taken from the program that Ministry of Education prescribed for the computer lesson. Expert opinion was received while the material was being created. In the test, questions about each concept in the context are included.

Test analysis procedure was carried out to determine the test items reliability and validity. For this purpose, firstly, the test was administered to 161 7th grade students in public school who took computer literacy course in a public elementary school. The difficulty and discrimination indices of each item are calculated in the item analysis. Items with a discrimination index of less than .20 were removed from the test. At the end of the analyzes, 6 items are not found valid reliable and discarded from the test. The remaining 26 items of test were used as pretest, posttest and retention test. The KR-20 value from the test was obtained as 0.75 .

\section{Collection of Data}

For data collection of this research, a Computer Literacy Achievement Test (CLAT) was developed by the researchers. The data were obtained by the application of this test.

\section{Analysis of Data}

Firstly, the CLAT was administered to experimental and control groups as pretest. The significance of pre-test achievement scores of the groups was examined by t-test.At the end of a four week application of the study, posttest was administered to the experimental and control groups. The obtained data were analyzed by t-test and the significance of the difference between the posttest success scores of the groups was analyzed.Three weeks after the application, a retention test was administered to the experimental and control groups. The obtained data were analyzed by t-test and the significance between the posttest and retention test scores of the groups was examined.

\section{Findings}

In this section, findings and discussion obtained as a result of statistical analysis of data are presented. It has been investigated whether there is a meaningful difference between cooperative learning and traditional methods in terms of academic achievement and retention of the learners.

An independents groups t-test analysis was conducted to determine whether there was a significant difference between the pretest scores of the experimental and control groups, and the results are presented in Table 2. 
Tekdal \& Sönmez - Çukurova Üniversitesi Eğitim Fakültesi Dergisi, 47(1), 2018, 37-59

Table 2.

Independent Groups t-test Analysis Results of Pretest of Experimental and Control Groups.

\begin{tabular}{lllcccc}
\hline Tests & Groups & $\mathrm{N}$ & $\overline{\mathrm{X}}$ & $\mathrm{SD}$ & $\mathrm{t}$ & $\mathrm{p}$ \\
\hline \multirow{2}{*}{ Pretest } & Experimental & 33 & 15.12 & 4.526 & & \\
& & & & & 1.397 & 0.168 \\
& Control & 22 & 13.41 & 4.339 & & \\
\hline
\end{tabular}

When Table 2 is examined, it is seen that there is no significant difference between the pretest average score $(\bar{X}=15.12)$ of the experimental group and the average score $(\bar{X}=13.41)$ of the control group $(p>.05)$. In the light of this finding, it can be said that the experimental group in which the cooperative learning method is applied and the control group in which the traditional method is applied are equivalent according to the academic success in the computer literacy course before the application. In another word, there is no difference between the sixth grades in terms of computer literacy pre-test scores.

A paired groups t-test analysis was conducted to determine whether there was a significant difference between the pretest and posttest scores of the experimental groups, and the results are presented in Table 3.

Table 3.

Paired groups t-test analysis results of pretest and posttest of the experimental group.

\begin{tabular}{lcccccc}
\hline Tests & Groups & $\mathrm{N}$ & $\mathrm{X}$ & $\mathrm{SD}$ & $\mathrm{t}$ & $\mathrm{p}$ \\
\hline Pretest & & 33 & 15.12 & 4.526 & & \\
& Experimental & & & & -4.925 & 0.000 \\
Posttest & & 33 & 18.76 & 3.717 & & \\
\hline
\end{tabular}

From Table 3, it can be seen that the posttest average score $(\overline{\mathrm{X}}=18.76)$ is significantly different from pre-test average score $(\bar{X}=15.12)$ of the experimental group $(p<0.05)$. For this reason, it can be said that cooperative learning method has significant positive effect on academic achievement in computer literacy course.

The paired groups t-test was conducted to determine whether there was a difference between the pretest-posttest scores of the control groups and the results are given in Table 4.

Table 4.

Paired Groups t-test Analysis Results of Pretest and Posttest of the Control Group.

\begin{tabular}{llccccc}
\hline Tests & Groups & $\mathrm{N}$ & $\overline{\mathrm{X}}$ & $\mathrm{SD}$ & $\mathrm{t}$ & $\mathrm{p}$ \\
\hline Pretest & Control & 22 & 13.41 & 4.339 & & \\
& & & & & -3.278 & 0.004 \\
Posttest & & 22 & 15.41 & 3.390 & & \\
\hline
\end{tabular}

When Table 4 is examined, it is seen that the pretest average score $(\bar{X}=13.41)$ is significantly lower than posttest average score $(\bar{X}=15.41)$ of the control group $(p<0.05)$. Thus, it can be said that the traditional way of learning has influenced success in a positive way. The results in Table 2 and Table 3 above indicate that there is an increase in academic achievement for both experimental and control group after administration. Regardless of the methods used here, it seems that the learning has taken place. However, it can be said that the development in the experimental group in which the cooperative learning method is applied is more advanced. 
Tekdal \& Sönmez - Çukurova Üniversitesi Eğitim Fakültesi Dergisi, 47(1), 2018, 37-59

Independent groups t-test was used to determine whether there was a significant difference between the posttest scores of the experimental and control groups and the results are presented in Table 5.

Table 5.

Independent Groups T-test Analysis Results Of Posttest Of Experimental And Control Groups.

\begin{tabular}{lllcccc}
\hline Tests & Groups & $\mathrm{N}$ & $\overline{\mathrm{X}}$ & $\mathrm{SD}$ & $\mathrm{t}$ & $\mathrm{p}$ \\
\hline \multirow{2}{*}{ Posttest } & Experimental & 33 & 18.76 & 3.717 & & \\
& & & & & 3.388 & 0.001 \\
& Control & 22 & 15.41 & 3.390 & & \\
\hline
\end{tabular}

In Table 5, it is seen that the posttest average score $(\bar{X}=18.76)$ of the experimental group, which followed the computer literacy course by cooperative learning method, is higher than the posttest average score ( $\bar{X}=15.41$ ) of the control group which followed with traditional methods and techniques. As a result of the t-test analysis, it is seen that there is a significant difference between experimental and control groups posttest average scores in favor of the experimental group $(p<0.05)$. Also it can be said from these results, students are more successful when they work together. Briefly, it can be concluded that cooperative learning method is more effective than traditional methods on academic achievement in computer literacy course.

The paired t-test analysis was used to determine whether there was a significant difference between the posttest-retention test scores of the experimental and control groups and the results are presented in Table 6 and Table 7.

Table 6.

Paired Groups T-test Analysis Results Of Posttest And Retention Test Of The Experimental Group.

\begin{tabular}{llccccc}
\hline Tests & Groups & $\mathrm{N}$ & $\mathrm{X}$ & $\mathrm{SD}$ & $\mathrm{t}$ & $\mathrm{p}$ \\
\hline Posttest & & 33 & 18.76 & 3.717 & & \\
& Experimental & & & & 3.514 & 0.110 \\
Retention & & 33 & 17.76 & 2.905 & & \\
\hline
\end{tabular}

When Table 6 is examined, it is seen that there is no significant difference between the posttest average score $(\bar{X}=18.76)$ and the retention test average score ( $\bar{X}=17.76)$ of the experiment group instructed with computer-based cooperative learning method ( $p>0.05$ ). So, it can be said that the students learning is permanent when cooperative learning method jigsaw technique used.

Table 7.

Paired Groups T-test Analysis Results Of Posttest And Retention Test Of The Control Group.

\begin{tabular}{lcccccc}
\hline Tests & Groups & $\mathrm{N}$ & $\overline{\mathbf{X}}$ & $\mathrm{SD}$ & $\mathrm{t}$ & $\mathrm{p}$ \\
\hline Posttest & & 22 & 15.41 & 3.390 & & \\
& Control & & & & 0.310 & 0.587 \\
Retention & & 22 & 15.05 & 4.766 & & \\
\hline
\end{tabular}

When Table 7 is examined, it is seen that there is not a significant difference between the posttest average score $(\bar{X}=15.41)$ and the retention test average score $(\bar{X}=15.05)$ of the control group who took computer literacy course with traditional methods and techniques $(p>0.05)$. The traditional way of learning is also support retention of what is learned. 
Tekdal \& Sönmez - Çukurova Üniversitesi Eğitim Fakültesi Dergisi, 47(1), 2018, 37-59

Table 8 shows the results of the independents group t-test analysis conducted to determine whether there is a significant difference between the retention test scores of the experimental and control groups.

Table 8.

Independent Groups T-test Analysis Results Of Retention Test Of Experimental And Control Groups.

\begin{tabular}{llccccc}
\hline Tests & Groups & $\mathrm{N}$ & $\overline{\mathbf{X}}$ & $\mathrm{SD}$ & $\mathrm{t}$ & $\mathrm{p}$ \\
\hline \multirow{2}{*}{ Retention } & Experimental & 33 & 17.76 & 2.905 & & \\
& & & & & 2.625 & 0.011 \\
& Control & 22 & 15.05 & 4.766 & & \\
\hline
\end{tabular}

When Table 8 is examined, it is seen that the average score of the retention test of experimental group $(\bar{X}=17.76)$ is higher than the average score of the control group $(\bar{X}=15.05)$. So it can be said that there is a significant difference between retention scores of the experimental and control groups in favor of the experimental group. $(p<0.05)$. As a result; it can be said that the cooperative learning method is more effective than the traditional method in terms of the retention of the learners in the computer literacy course.

\section{Conclusions \& Discussion}

In this research, it was investigated whether teaching Computer Literacy lesson with jigsaw collaborative learning method had an effect on academic achievement and retention of 6th grade primary school students.

The study was conducted with two groups as experimental and control groups consisted of 55 students 33 in experimental groups and 22 in control groups. A pre-test was applied to the students who participated in the research.The significance of the difference between pretest scores of the experimental group and the control group was examined and no significant difference was found. At the beginning, it was determined that both groups were equal in terms of success for the Computer Literacy course. Both groups were posttested after the application and it was found that the experimental group was more successful than the control group. So it can be concluded that learning Computer Literacy subject with jigsaw collaborative learning method is more effective than traditional learning method. Finally, three weeks after the study, the same test was applied to both experimental and control groups to determine the retention of the learners and no significant difference was found between the retention test score and the posttest score in both experimental and control groups. In another word, we can conclude that the students can remember what they learn without difference of applied learning method.

Based on results of this research, it can be concluded that using Jigsaw cooperative learning technique was an effective teaching method for Computer Literacy class. This result may be due to characteristics of Jigsaw cooperative learning technique such as study with teams in active learning environments and cooperate with other students.

Nevertheless, we cannot say that the jigsaw method gives much superiority to the traditional methods when teaching computer literacy. Because, the pretest meanscore of the experimental and control groups were 15.12 and 13.41 respectively. When these scores were compared with the post-test scores, it was seen that there was an increase of approximately 3.35 questions in the experimental group and an increase of 2 questions in the control group. Therefore, teaching with the jigsaw method causes only 1 to 1.5 more questions to be made by students. This may be due to students being in the same environment and interacting with each other. In addition, the liking and attractiveness of computer lessons among students may have played a role in this situation.

The findings of this study, also consistent with a number of researches (Artut, \& Tarim, 2007;Berger \& Hänze, 2015; Doymus, 2008; Gömleksiz, 2007;Mari, \& Gumel, 2015; Mengduo, \& Xiaoling, 2010; 
Tekdal \& Sönmez - Çukurova Üniversitesi Eğitim Fakültesi Dergisi, 47(1), 2018, 37-59

Olukayode \& Salako, 2014; Sevim, 2015; Şahin, 2011; Tarhan, Ayyıldız, Ogunc \& Sesen, 2013; Wyk, 2012) in literature that support the positive findings of learning effect of the cooperative learning techniques on students' achievement over traditional teaching methods. However, a small number of studies have also been published showing that the collaborative method has less or equal effect on learning than the traditional method. For example, Hänze \& Berger (2007) reported that their study failed to show positive effects of the jigsaw technique on academic performance. In their study, students in 12th grade physics classes participated in a quasi-experimental study comparing the jigsaw cooperative method with traditional direct instruction method. Although, this contrast results for the jigsaw technique somewhat contrasts the literature of cooperative learning, Slavin, Hurley, and Chamberlain (2003) argue that the research on cooperative learning is one of the greatest success stories in the history of educational research.

Surprisingly, although there was no significant difference between retention test scores, there was a statistically significant difference between the posttest scores of the experimental and control groups. This may be due to administering of the same test as both a posttest and a retention test to both experimental and control groups.

From the results of this study, it is clear that jigsaw technique is an effective cooperative learning method to improve learning and provide students an effective and enjoyable learning environment. Based on the finding of this study, researchers would like to provide these recommendations: (1) only 6 th grade (11-13 year old) students participated in this research. Computer literacy teaching with collaborative learning method can be used to investigate the outcomes of applying to different age group students, $(2)$ the conditions of the computer lab in this research were very limited. There was no internet connection in the lab. There were missing equipment, such as a printer and a scanner. Different results may occur when physical conditions are changed and applied, (3) It can be evaluate students reasoning ability to know how adopt grouping for cooperative learning. So every student can be benefit from group, and (4) in the application of collaborative learning method, what kind of problems the teacher is encountering in class management and group formation can be investigated. 


\section{Türkçe Sürümü}

\section{Giriş}

Öğretim etkinliklerinin istenen öğrenmeyi sağlaması için uygun yöntem ve teknikler kullanılmalıdır.Her ders için bir öğretim yönteminin etkili olması olası değildir.Öğretmenler, öğrencilerin öğrenme hız ve seviyesine ve konunun niteliğine göre farklı öğretim yöntem ve tekniklerini bilmeli ve kullanmalıdır.

Bilgisayar okuryazarlığı öğretiminde, öğrenmeye yönelik çeşitli yöntemler ve teknikler, yapılan araştırmaların ışığında daha kolay ve daha etkili hale gelir.Bununla birlikte, Türkiye'de devlet okullarının fiziki koşullarının yetersizliği ve sınıfların kalabalığı, öğretim yöntem ve tekniklerinin etkin kullanımını engellemektedir.Bu nedenle kullanılacak olan yöntemler, okulların koşulları dikkate alınarak belirlenmelidir.Özellikle kalabalık sınıflar bilgisayar laboratuvarlarında bilgisayarların yetersiz kalmasına neden oluyor.Laboratuvarlarda bilgisayar başına 3-4 öğrenci bulunmaktadır.Bu nedenle, öğrencilerin birlikte çalışarak öğrenecekleri yöntemleri uygulamak, öğrenmeyi daha verimli ve etkili hale getirecektir.

\section{Amaç}

Bu çalışmada, bilgisayar okur-yazarlığının öğretilmesinde İşbiirlikli öğrenme yöntemi birleştirme tekniğinin kullanılmasının öğrencinin başarısı ve öğrenilen kalıcılığı üzerineetkisi araştırılmıştır. Bu amac dayanarak, aşağıdaki araştırma sorularına yanıt aranmıştır.

3. Deney ve kontrol grubundaki öğrenciler arasında akademik başarı açısından anlamlı bir fark var midır?

4. Deney ve kontrol grubundaki öğrenciler arasında öğrenilenlerin kalıcılığı açısından anlamlı bir fark var mıdır?

\section{Araştırmanın Önemi}

Literatür taraması çalışmalarında, farklı düzeylerde ve sınıflarda ve işbirlikli öğrenme yöntemlerinin kullanıldığı bir çok araştırmanın olduğu bulunmuştur. Örneğin, fiziksel değişimlerden ve asit-baz reaksiyonlarından şekil ve moleküler çözünürlükteki değişimler, yanma reaksiyonları ve kimyasal değişikliklerden kaynaklanan ısınmaya bağlı değişiklikler (Tarhan ve diğerleri 2013), etnik bütünleşme ve sürdürülebilir kalkınma (Olukayode \& Salako, 2014), mühendislik öğrencilerine yönelik yabancı dil olarak İngilizce kelime bilgisi ve aktif-pasif öğrenme (Gömleksiz, 2007), yazılı anlatıma etkisi (Şahin, 2011), öğrencilerin öz-yeterlik ve kimyadaki başarısı üzerindeki etkisi (Mari \& Gumel, 2015),öğretim kalitesinin öğrencilerin akademik performansına etkisi (Berger ve Hänze, 2015), yüksek okul İngilizce dersinde başarıya etkisi (Mengduo \& Xiaoling, 2010),üçüncül düzeyde kimyasal bağlar öğretmek (Doymus, 2008), oran/orantı ve ölçme konularının öğretilmesinde (Artut \& Tarim, 2007)ve ekonomi eğitiminde (Wyk, 2012).Ancak, Bilgisayar Okuryazarlığı dersi öğretiminde işbirlikli öğrenme, birleştirme öğrenme tekniğinin kullanımı konusunda pek fazla araştırma yapılmamıştır. Bu araştırmaya dayanarak bilgisayar okuryazarlığı dersinde işbirlikçi öğrenme yöntemininbirleştirme tekniğinin etkinliği değerlendirilmiştir. Bu araştırmanın aşağıdaki konularda yarar sağlayacağı düşünülmektedir:

1. Bilgisayar okuryazarlığı öğretiminde kullanılacak yöntemlerin seçiminde bilimsel veri sağlamak.

2. İşbirlikli öğrenme yönteminden yaralanarak birbirleriyle iletişim kurabilen, bildiklerini paylaşan, kendinden emin hissetme ve birlikte çalışmayı bilen daha nitelikli bireyler yetiştirmek.

3. illkokullarda bilgisayar okuryazarlığı öğreten öğretmenlere ışık tutmak, daha verimli ve etkili öğretimin nasıl yapılacağına dair yeni fikirler sunmak ve daha sonra bilgisayar okuryazarlığı öğretimi üzerine çalışmalara yol göstermek. 


\section{Sayıltılar}

Bu çalışmada aşağıdaki varsayımlar benimsenmiştir;

1. Öğrencilerin, uygulanan testlere doğru ve samimi olarak cevap verdikleri varsayılmıştır.

2. Kontrol edilemeyen değişkenlerin, deney ve kontrol gruplarının her ikisini de aynı şekilde etkilediği varsayılmıştır.

3. Hazırlanan başarı testlerinin kapsam geçerliliği konusunda uzman görüşlerinin yeterli olduğu varsayılmıştır.

\section{Sınırlılıklar}

Bu araştırma;

1. Bir devlet ilköğretim okulunda okuyan 6. sınıf öğrencileri,

2. Bilgisayar dersinin bir ünitesi,

3. Okulun laboratuar koşulları,

4. İşbirliğine dayalı öğrenme yönteminin birleştirme tekniği ile sınırlıdır.

\section{Kuramsal Bilgiler ve İlgili Araştırmalar}

\section{İşbirlikli Öğrenme}

İşbirlikli öğrenme, "ortak öğrenme hedeflerini en üst düzeye çıkarmak için bir birimdeki küçük öğrenci gruplarında (2-4 kişi) birlikte çalışma prensibine dayanan etkileşimli öğrenme-öğretme yöntemi" olarak tanımlanmaktadır (Johnson, \& Smith, 1999).

Çağdaş eğitim kavramı, öğretmenlere, maksimum öğrenme düzeyinde gerçekleştirilecek öğretim yöntemini uygulama yükümlülüğü ve sorumluluğunu getirmiştir.Ancak, öğretmenlerin çoğu, belirtilen ders kitaplarına (mevcut müfredat programlarının etkisiyle) ve öğrencilerin pasif dinleyici olarak katılımlarına dayanan geleneksel öğretim yöntemini kullanmaktadır.Bazı öğretmenlerin, öğrencilerin aktif olarak dahil olduklarına inanarak baskı (dikte) yöntemini kullandıkları bilinmektedir.öğrenme ve öğretimin belirli bir düzeyde gerçekleştiği bu klasik yöntemlere rağmen, araştırmalar, bu yöntemlerin birçok öğrenci için anlamlı ve verimli olmaktan uzak olduğunu göstermektedir.Lazarowitz, öğretmenmerkezli ders anlatma yöntemini, yalnızca çalışkan öğrencileri cesaretlendirmek, bireysel çalışma ve rekabet yoluyla öğrenmelerini teşvik etmek ve sınıftaki tüm öğrencilerin sınıfın akademik ve sosyal gelişimine yeterince katkıda bulunmamasını eleştirerek, ısrarla öğretmenlerin diğer yöntemleri kullanmalarını önermektedir.Lazarowitz'e (1995) göre, anlatı yönteminin, özellikle anlama güçlüğü çeken öğrenciler için birçok dezavantajı vardır, çünkü öğrencilerden düşüncelerini açıklamak, tartışmak ve anlamak için yeterli değildir.Slavin (1990), tatmin edici bir eğitim ortamının, öğrencilerin zihinsel olarak aktif katılımcılar olduğu, bilgiyi akıl yoluyla içselleştirdiği, fikirlerin birleştirilip test edilebileceği bir ortam olması gerektiğini vurgular. Ayrıca, öğrencilerin bireysel düşüncelerini özgürce birbirlerini açıklayabilecekleri, tartışabilecekleri ve dinleyebilecekleri ortamların, öğrenme etkinliklerini daha verimli ve hızlı hale getirdiğini de belirtmiştir.

İşbirlikli Öğrenme Yöntemi, aynı zamanda problem çözme ve yaratıcı düşünme için etkili bir araçtır.Bireysel öğrenme yöntemlerinden farklı olarak, bu yöntem öğrencilerin problemleri çözmek için birlikte çalıştıkları ilkesine dayanmaktadır.Yani, bir problemi birlikte çözmek, daha fazla çözüm önerisi üretmek demektir.Yaratıcı düşüncenin en etkili araçlarından biri olan Beyin Fırtınası Yöntemi de birlikte çalışması gereken bir stratejidir.

İşbirlikli öğrenme ortamında, öğrencilerin kendi öğrenmelerini artırma ve birbirlerini öğrenme gibi ortak bir hedef doğrultusunda kişisel olarak birlikte çalışmalarını sağlamak amacıyla küçük gruplar eğitim amaçlı kullanıır.Grup üyeleri yetenek, kişilik özellikleri, cinsiyet, akademik başarı ve sosyal beceriler 
açısından farklıdır.Böylece bu öğrenme yöntemi her yaş grubuna, derse ve konu alanına başarıyla uygulanabilir.

İşbirlikli öğrenme klasik grup çalışmasına benzer, ancak her grup çalışması işbirlikli öğrenme değildir.Bir grup çalışmasının işbirlikçi öğrenme olması için, gruptaki öğrenciler hem kendileri hem de diğer üyelerin öğrenmelerini en üst düzeye çıkarmaya çalışmalıdır. Işbirlikli öğrenmenin gerçekleşmesi için, bir gruptaki öğrencilerin birbirlerinden bağımsız olarak çalışmanın bir kısmını yapmaktan ziyade birbirleriyle iletişim kurması ve işbirliği yapması gerekir.Küçükahmet'e (1997) göre, öğrenciler sadece duyduklarını unuturlar, ancak kendileri de katıldıkları bir eğitim faaliyeti, onların daha iyi anlamasına ve kolayca unutamayacaklarına yardımcı olur.

İşbirlikçi öğrenme, her bir yaş grubunda, her dersin öğretiminde ve her bir konu alanı düzeyinde başarıyla uygulanan bir öğrenme yöntemidir."Sınıfların kalabalıklaşması yöntemi uygulamakta zorlanır" inancı vardır.Ancak araştırmalar, kalabalık sınıflarda da başarıı bir şekilde uygulanabileceğini göstermektedir (Steiner, Stromwall, Brzuzy \& Gerdes, 1999).

Genel olarak iki tür işbirlikçi öğrenme kümesi oluşturulabilir, yapılandırılabilir ve yapılandırılamaz. Yapılandırılmış işbirlikçi öğrenme kümeleri, birkaç gün ila birkaç hafta süren iyi tanımlanmış bir konu olan belirli sayıda öğrenciden oluşan kümelenmelerdir. Planlama uygulaması ve değerlendirmenin aşamalarının zaten belli olduğu konu alanı için teknikler tanımlanabilir ve bunların uygulanması belirli bir süre gerektiren tekniklere dayanır. Öte yandan, yapılandırılmamış işbirlikçi öğrenme kümeleri geçici olarak oluşturulmakta ve sadece bir tartışma veya kursun sonuna kadar kullanılmaktadır (Holubec, Johnson, \& Johnson, 1993).

Aronson (2002) ve meslektaşları tarafından geliştirilen iş̧irlikli öğrenme yöntemi birleştirme tekniğinin temelleri, yazarların Grup Dinamiği ve Sosyal Etkileşim alanlarında uzun yıllara dayanan çalışmalarına dayanmaktadır.Bu "Saf" işbirliğine dayalı öğretim tekniklerinden birisidir.

Bu teknikte öğrencilerden 3-6 kişilik guruplar oluşturulur. Akademik materyal (ünite) 3-6 bölüme(konuya) ayrılır. Her kümeye aynı ünite verilir ve küme üyelerinden konulardan birini seçmesi istenir.Her üye kendi konusuna çalışır. Daha sonra farklı kümelerde aynı konuyu alan üyeler 'uzmanlık kümelerinde' bir araya gelirler; konu üzerinde tartışıllar. Daha sonra kendi gruplarına geri dönerler.Yeniden bir araya gelen grup üyeleri hazırladıkları konuları birbirine öğretmekle yükümlüdür.Onlara bunun için belli bir süre verilir ve bu sürenin sonunda bireysel olarak o konuyla ilgili sınava girecekleri söylenir.Birleştirme tekniğinde, konunun tümünün öğrenilebilmesi için öğrenciler birbirini dinlemek durumundadır.Yani olumlu bağımlılık oldukça yüksektir.Ayrıca her öğrenci hem öğreten hem de öğrenen durumundadır.Dolayısıyla bazı öğrencilerin baskınlığı önlendiği bir ortam oluşur.Grup içerisinde herkesin katkısı değerlidir.

Bu teknikte öğrenciler diğer konuları sadece arkadaşlarını dinleyerek öğrenebilirler.Öğrencilerin diğer arkadaşlarının çalışmaları için ilgi ve destek göstermeleri beklenir.öğrenciler kümede birbirlerini eğitmeyi bitirdikten sonra, her öğrenci birim sınavına bireysel olarak girer.Bireyler bu sınavdan puan alırlar.

\section{Bilgisayar Okur-yazarlığı ve İ̧̧birlikli Öğrenme}

21 'inci yüzyılda, Türkiye'de ilköğretimdeki temel amaçlardan biri, diğer tüm ülkelerde olduğu gibi, öğrencilerin küreselleşmenin yönelimi yönündeki değişimler sonucunda etkili bir şekilde öğrenmelerini sağlayan etkili ve verimli bir bilgisayar okuryazarlığı öğrenme ortamı sağlamaktır.Gelişmeler, bu yüzyılda Bilgisayar Okuryazarlığııın, çağdaş bir insan için kaçınılmaz bir intiyaç haline geleceğini göstermektedir.Bu beceriye sahip olmayan bireylerin iş bulma, kendilerini geliştirme ya da üretime katkıda bulunma fırsatlarına sahip olamayacağı açıktır. Dolayısıyla, okuryazarlık artık temel bilgisayar becerilerini içermelidir (Orhan, 1995).Bu nedenle bilgisayar okuryazarlı̆ını öğretmek için daha etkili yöntemlerin kullanılması gerekmektedir.

Öte yandan, çoğunlukla öğretmen-merkezli geleneksel öğretim yöntemleri, öğrencilerin her zaman bilginin pasif alıııları oldukları derse dayalı yöntemlere odaklanmışlardır.Bununla birlikte, son yıllarda 
öğrenci merkezli öğretim yöntemlerine doğru kayda değer bir değişim olmuştur.Öğrenme ortamında işbirlikli öğrenme yöntemi kullanıldığında, sınıftaki tüm öğrenciler aynı zamanda bir göreve aktif olarak katılırlar.Böylelikle öğrenciler bulgularını tartışabilir ve karşılaştırabilirler (Yang ve Cheung, 2003). Dolayısıyla, bu modern öğrenme yöntemleri arasında yer alan işbirlikli öğrenme yöntemi, bilgisayar okuryazarlık sınıflarında etkili bir şekilde kullanılabilir.

Yukarıda belirtildiği gibi işbirlikli öğrenme, eğitimdeki en popüler, verimli teori, araştırma ve uygulama alanlarından biridir. Bu teori, araştırma ve uygulama birleşimi, işbirlikli öğrenmeyi tüm öğretim uygulamalarından en belirgin olanlarından biri haline getirmektedir (Johnson, Johnson ve Stanne, 2000) ve bu işbirlikçi çabalar genellikle öğrencileri hedefleyen hedefleri ve öğretim prosedürlerini gerçekleştirmek için birlikte çalışan öğrencileri ifade eder.Uygulamalı bilimlerde işbirlikli öğrenme yönteminin başarısı, literatür çalışmalarında sıklıkla yer almıştır.Örneğin, Biyoloji (Haack, 2014), Fizik (Gambari ve Yusuf, 2016), Kimya (Apugliese \& Lewis, 2017; Warfa, 2015), Matematik (Capar \& Tarim, 2015; Alabekee, Samuel ve Osaat, 2015) , Bilim ve Teknoloji (Altun, 2015), Bilgisayar Bilimleri (Othman, Hussain ve Nikman, 2017). Bu bağlamda, bilgisayar okuryazarlı̆ı çoğunlukla uygulamalı bir bilim olduğundan, işbirlikli öğrenmenin bu doğasının bilgisayar okuryazarlığının öğretilmesinde önemli bir rol oynayabileceği söylenebilir.

Bilgisayar okur-yazarlığı, bilgisayar bilincinden programlama dillerine kadar uzanır. Araştırmalar, bilgisayarları günlük yaşamda ihtiyaç duydukları kadar kullanma yeteneğine sahip olma gereksinimini vurgulamaktadır. Böylece, bilgisayar okuryazarlığı eğitimi, bilgisayar ve temel kavramları elde etmek, bilgisayar hedefleri ve beklentileri doğrultusunda kullanılacak beceriler geliştirmek ve bilgisayar bilimi alanındaki gelişmeleri takip etme alışkanlığını kazandırmak amacıyla yapılan eğitim olarak tanımlanmaktadır (Keser ve Teker, 2011).

Bilgisayar okur-yazarlığı eğitimi, araştırma yapmak ve bilgi toplamak için bilgisayar teknolojisinin nasıl kullanıldı̆̆ını öğrenmeyi amaçlamaktadır. Bunun yanı sıra, bilgisayar kültürleri, metinler, illüstrasyonlar, oyunlar ve etkileşimli multimedya ile yeni okuryazarlık biçimlerinin geliştiği bir alan olarak görülmektedir. Dahası, bilgisayar kültürü, öğrenenlerin, öğretmenlerin ve vatandaşların tartışma grupları, araştırma projeleri, web siteleri, multimedya ve diğer yeni öğrenme ve sosyal etkileşim biçimleriyle birleştiği söylemsel ve politik bir alandır.

Aytaç'a (2000) göre, genişletilmiş bilgisayar okuryazarlığı; bilgisayarı nasıl kullanacağını, bilgiye nasıl ulaşacağını, eğitim materyallerini, e-posta ve listeleme servislerini ve web sitesinin nasıl hazırlanacağını öğrenmektir.Bilgisayar okuryazarlı̆ı, çok farklı türde bilginin geliştirilmesini ve kullanıımasını içeren bilgi toplumudur.Bu, yeni internet web sitelerinde ve arama motorlarında olduğu gibi, işbirlikçi yapı (kütüphaneler gibi) ve yazılı medya yerine yeni bilgi kaynaklarına erişmenin yeni yollarını da öğrenmeyi içerir.Bilgisayar okuryazarlığı ayrıca, nerede bulacağınızı, oraya nasıl ulaşacağını, nasıl yorumlanacağııı ve bilginin değerini nasıl ölçeceğini öğrenmeyi de içerir.

\section{Method}

Bu bölümde yöntem, araştırma modeli, çalışma grubu, deneysel desen, uygulama, veri toplama araçları, veri toplama süreci ve verilerin analizi açıklanmıştır.

\section{Araştırma Modeli}

Bu çalışma, 6.sınıf ilkokul öğrencilerine bilgisayar okuryazarlığını öğretmede işbirlikli öğrenme yönteminin etkinliğini araştırmıştır. Çalışma, bir devlet ilkokulundaki, bilgisayar dersini alan altıncı sınıf öğrencileri ile gerçekleştirilmiştir. Rastgele seçilen iki sınıf deney ve kontrol grubu olarak oluşturulmuştur. Deney grubuna işbirlikli öğrenme yöntemi birleştirme tekniğiyöntemi, kontrol grubuna ise geleneksel yöntem ve teknikler (ders, soru-cevap, demonstrasyon, bireysel çalışma ve eğitim oyunları) uygulanmışır. Kullanılan yöntemlerin akademik başarı ve kalıcılık üzerindeki etkilerini belirlemek için "Ön Test Son Test Kontrol Gruplu Model" kullanılmıştır.Araştırma modelinin deneysel tasarımı Tablo 1'de gösterilmiştir. 
Tablo 1.

Araştırma Modelinin Deneysel Tasarımı.

\begin{tabular}{lcccc}
\hline Gruplar & Öntest & Yöntem & Sontest & Kalıcılık Testi \\
\hline Deney & $\mathrm{O}_{1.1}$ & $\mathrm{X}_{1}$ & $\mathrm{O}_{1.2}$ & $\mathrm{O}_{1.3}$ \\
Kontrol & $\mathrm{O}_{2.1}$ & $\mathrm{X}_{2}$ & $\mathrm{O}_{2.2}$ & $\mathrm{O}_{2.3}$ \\
\hline
\end{tabular}

$\mathrm{O}_{1.1}$ :Deney gurubu için öntest

$\mathrm{O}_{2.1}$ :Kontrol gurubu için öntest

$\mathrm{X}_{1}:$ İ̧̧birliğine Dayalı Öğrenme Yöntemi (Birleştirme Tekniği)

$X_{2}$ :Geleneksel Öğrenme Yöntemi

$\mathrm{O}_{1.2}$ :Deney gurubu için sontest

$\mathrm{O}_{2.2}$ : Kontrol gurubu için sontest

$\mathrm{O}_{1.3}$ : Deney gurubu için kalıcılık testi

$\mathrm{O}_{2.3}$ :Kontrol gurubu için kalıcılık testi

\section{Çalışma Grubu}

$\mathrm{Bu}$ araştırmanın çalışma grubu, bir devlet ilköğretim okulunda bilgisayar dersi alan 6 . sınıf öğrencilerinden oluşmaktadır. Rasgele olarak seçilen iki sınıftan biri deney grubu, diğeri kontrol grubu olarak belirlenmiştir.Deney grubunda 16 kız, 17 erkek öğrenci bulunmaktadır.Kontrol grubunda ise 11 kız, 11 erkek öğrenci bulunmaktadır.

\section{Uygulama}

Uygulama, Bilgisayar ve Öğretim Teknolojileri Eğitimi Bölümü'nden mezun ve 5 yıllık deneyime sahip bir bilgisayar öğretmeni tarafından gerçekleştirilmiştir.

Bu çalışma, biri deney ve diğeri kontrol grubu olmak üzere iki grup ile yapılmıştır.Deneysel çalışmaya başlamadan önce, hem deney hem de kontrol grubu öğrencilerine bir ön test uygulanmıştır.Araştırmanın kontrol grubunda, sürekli olarak kullanılan ve alışılagelmiş yöntemle ders işlenmiştir.Öğretmenin daha etkin olduğu bu yönteme 'geleneksel yöntem' adı verilmiştir.

Dersten önce, öğrencilere dersin nasıl ele alınacağı ve ders sırasında izlenecek kurallar hakkında bilgi verilir.Öğrencilerin ders sırasında soru sormalarına ve bilgisayar laboratuarını mesai dışı saatlerde kullanmalarına izin verilmiştir.Öğrencilerin başarı değerlendirmesi dönem ortası ve sonunda iki defa olmak üzere test uygulaması şeklinde yapılmıştır.

Deney grubuna ise işbirliğine dayalı öğrenme yönteminin tekniklerinden biri olan birleştirme tekniği uygulanmıştır.Araştırmanın deney grubu içinde 3-4 öğrenciden oluşan işbirliğine dayalı öğrenme grupları oluşturulmuştur.3 grup 3'er öğrenci, 6 grup da 4'er öğrenciden olmak üzere 9 grup oluşturulmuştur.Gruplar oluşturulurken, öntest uygulaması sonucu değerlendirilerek, öğrenciler en yüksek ortalamadan en düşük ortalamaya doğru sıralanmıştır.İşbirliğine dayalı öğrenme yönteminin karma gruplar ilkesi göz önünde bulundurularak gruplar kendi içinde karma (cinsiyet ve başarı durumları göz önüne alınarak), gruplar arası ise homojen olacak şekilde oluşturulmuştur.

Uygulamaya başlamadan önce:

1. Öğrencilere yapılacak çalışma ile ilgili bilgi verilmiştir.

2. Grupların görevleri açıklanmış, uzmanlık gruplarının nasıl oluşturulacağı ve uzmanlık gruplarında yapılacak çalışmalar anlatılmıştır.

3. Öğrenilecek tüm içeriği kapsayan etkinlik için örnek bir gazete kupürü öğrencilere gösterilmiştir. 
Tekdal \& Sönmez - Çukurova Üniversitesi Eğitim Fakültesi Dergisi, 47(1), 2018, 37-59

4. İçerikteki farklı boyutta yazı, yazı tipi, rengi, resimler ve resimlerin yerleştiriliş biçimleri, yazının ortalanması ya da sağa veya sola yaslı yazılması kavramları tahtaya yazılmış ve öğrencilere açıklanmıştır.

5. Her grubun aynı çalışmayı yapacağı öğrencilere bildirilmiş ve grup üyelerinin içerikte yer alan kavramları öğrenmek üzere paylaşması istenmiştir.

6. Grup üyelerinin tek başlarına görevleri ve gruba karşı sorumlulukları hakkında bilgi verilmiştir.

Bilgisayar okuryazarlığının, 4 haftave haftada 2 saat boyunca işbirlikli öğrenme yönteminin birleştirme teknikleriyle öğretilmesi, aşağıdaki adımlarla gerçekleştirilmiştir.

4. İçeriğin Paylaşımı:Deney grubunda öncelikle 3 ila 4 öğrenciden oluşan işbirlikli öğrenme temelli öğrenme grupları oluşturulmuştur. Daha sonra, Microsoft Word kelime işleme yazılımının Standart ve Biçim araç çubuklarındaki kavramlar öğrenciler arasında paylaşıldı ve gruptaki her bir öğrenciye konunun bir bölümünü paylaşması için bir konu verildi. Örneğin, 2 nolu öğrenci, Kalın, İtalik, Alt çizgi, Sola hizala, Ortala, Sağa hizala, Yasla ve diğer arkadaşlarının seçtiği konuları inceler.

5. Uzmanlık Grupları Oluşturmak:Bu aşamada öğrenciler kendi gruplarından ayrıldı ve aynı kavramdan sorumlu öğrencilerle yeni gruplar oluşturuldu. Bu gruplara "uzmanlık grupları" denir. Uzman gruplarda öğrenciler konularını daha net bir şekilde öğrenmeye çalışmışlar ve kendi gruplarına geri dönmüşlerdir. Örneğin, bu öğrencilerden biri seçtikleri kavramları öğrenmek için çalışır, ardından bu deneyimlerini kendi arkadaşlarıyla paylaşmak için uzmanlık grubuna katılır.

6. Grup içi Öğretim:Tekrar toplanan grup üyeleri, gruptaki diğer arkadaşlarına öğrendiklerini öğretiler. Grup üyeleri, grup içindeki her bir üyenin tüm kavramları öğrenmesine yardımcı olmak için birlikte çalışma konusunda birbirlerine yardımcı oldular.

\section{Bilgisayar Okuryazarlığı Başarı Testi}

Araştırmada, MEB'nın bilgisayar dersi için öngördüğü programdan alınan içerik ve içerik doğrultusunda belirlenen hedef ve davranışları kapsayan 32 maddelik, dörder seçenekli çoktan seçmeli bir bilgisayar okur-yazarlı̆ı akademik başarı testi hazırlanmıştır. Maddeler oluşturulurken uzman görüşü alınmıştır.Testte, içerikteki her kavramla ilgili sorulara yer verilmiştir.

Test maddelerinin güvenilirliğini ve geçerliliğini belirlemek için test analizi prosedürü gerçekleştirilmiştir. Bu amaçla öncelikle, bir devlet ilkokulunda bilgisayar okuryazarlığı dersi alan161 7. sınıf öğrencisine test uygulanmıştır. Her bir maddenin zorluk ve ayırıcılık endeksleri madde analizinde hesaplanmıştır.Bu maddeleden aırıcilık endeksi 0.20'den küçük olan maddeler testten çıkarılmıştır.Analizlerin sonunda 6 madde geçerli olarak güvenilir bulunmamıştır ve testten çıkarılmıştır.Geriye kalan 26 madde; ön test, son test ve kalıcılık testi olarak kullanıldı.Testin KR-20 değeri 0.75 olarak bulunmuştur.

\section{Verilerin Toplanması}

Bu araştırmanın verilerini toplamak için, araştırmacılar tarafından bir Bilgisayar Okuryazarlığı Başarı Testi (BOBT) geliştirilmiştir. Veriler bu testin uygulanmasıyla elde edilmiştir.

\section{Verilerin Analizi}

Öncelikle, deney ve kontrol gruplarına ön test olarak BOBT uygulanmıştır. Grupların ön test başarı puanları arasında anlamlı fark olup olmadıpı t-testi ile gerçekleştirilmiştir. Çalışmanın dört haftalık uygulamasının sonunda deney ve kontrol gruplarına son test uygulanmışır.Elde edilen veriler t-testi ile analiz edilmiş ve grupların en son başarı puanları arasındaki farkın anlamlı olup olmadığı analiz edilmiştir. 
Uygulamadan üç hafta sonra, deney ve kontrol gruplarına bir kalıcılık testi uygulanmıştır. Elde edilen veriler t-testi ile analiz edilmiş ve grupların son test ve kalıcılık testi puanları arasındaki fark incelenmiştir.

\section{Bulgular}

$\mathrm{Bu}$ bölümde, verilerin istatistiksel analizi sonucunda elde edilen bulgular ve tartışmalar sunulmuştur.İşbirlikli öğrenme ile geleneksel yöntem arasında öğrencilerin akademik başarıları ve bilgilerin kalıcılığı açısından anlamlı bir fark olup olmadığı araştırılmıştır.

Deney ve kontrol gruplarının ön test puanları arasında anlamlı bir fark olup olmadığını belirlemek için bağımsız gruplar t-testi analiziyapılmış ve sonuçlar Tablo 2'de sunulmuştur.

Tablo2.

Deney ve Kontrol Gruplarının Bağımsız Gruplar t-testi Analizi Öntest Sonuçları.

\begin{tabular}{llccccc}
\hline Testler & Groups & $\mathrm{N}$ & $\overline{\mathrm{X}}$ & $\mathrm{SD}$ & $\mathrm{t}$ & $\mathrm{p}$ \\
\hline \multirow{2}{*}{ Öntest } & Deney & 33 & 15.12 & 4.526 & & \\
& & & & & 1.397 & 0.168 \\
\hline
\end{tabular}

Tablo 2 incelendiğinde, deney grubunun ön test ortalama puanı ( $\bar{X}=15.12$ ) ile kontrol grubunun ortalama puanı ( $\bar{X}=13.41$ )arasında anlamlı bir fark olmadığı görülmüştür $(p>.05)$. Bu bulgu ışığında, işbirlikli öğrenme yönteminin uygulandığı deney grubunun ve geleneksel yöntemin uygulandığı kontrol grubunun, uygulamadan önce bilgisayar okuryazarlığı dersindeki akademik başarıya göre eşdeğer olduğu söylenebilir.Başka bir deyişle, bilgisayar okuryazarlığı ön test puanları bakımından altıncı sınıflar arasında bir fark yoktur.

Deney gruplarının ön test ve son test puanları arasında anlamlı bir fark olup olmadığını belirlemek için eşli gruplu t-testi analizi yapılmış ve sonuçlar Tablo 3 'te sunulmuştur.

\section{Tablo 3.}

Deney grubu öntest ve sontest eşli gruplar t-testi analiz sonuçları.

\begin{tabular}{lcccccc}
\hline Testler & Gruplar & $\mathrm{N}$ & $\mathrm{X}$ & $\mathrm{SD}$ & $\mathrm{t}$ & $\mathrm{p}$ \\
\hline Öntest & & 33 & 15.12 & 4.526 & & \\
& Deney & 33 & 18.76 & 3.717 & & 0.000 \\
Sontest & & 33.925 & \\
\hline
\end{tabular}

Tablo 3'te, sontest ortalama puanının ( $\overline{\mathrm{X}}=18.76)$, deney grubunun ön test ortalama puanından $(\overline{\mathrm{X}}=$ 15.12) anlamlı derecede farklı olduğu görülebilir $(p<0.05)$. Bu nedenle, bilgisayar okuryazarlığı dersinde işbirlikli öğrenme yönteminin akademik başarıya önemli oranda olumlu etkisi olduğu söylenebilir.

Kontrol grubunun öntest-sontest puanları arasında bir fark olup olmadığını belirlemek için eşli gruplar t-testi yapılmış ve sonuçlar Tablo 4 'te verilmiştir.

Tablo 4.

Kontrol grubu öntest ve sontest eşli gruplar t-testi analiz sonuçları.

\begin{tabular}{llccccc}
\hline Testler & Gruplar & $\mathrm{N}$ & $\overline{\mathrm{X}}$ & $\mathrm{SD}$ & $\mathrm{t}$ & $\mathrm{p}$ \\
\hline Öntest & Kontrol & 22 & 13.41 & 4.339 & & \\
& & & & & -3.278 & 0.004 \\
Sontest & & 22 & 15.41 & 3.390 & & \\
\hline
\end{tabular}


Tekdal \& Sönmez - Çukurova Üniversitesi Eğitim Fakültesi Dergisi, 47(1), 2018, 37-59

Tablo 4 incelendiğinde, ön test ortalama puanının $(\bar{X}=13.41)$ kontrol grubunun son test ortalamasından ( $\bar{X}=15.41)$ anlamlı derecede düşük olduğu görülmüştür ( $p<0.05)$. Dolayısıyla, geleneksel öğrenim tarzının başarıyı olumlu yönde etkilediği söylenebilir.Yukarıdaki Tablo 2 ve Tablo 3 'teki sonuçlar, uygulamadan sonra hem deney hem de kontrol grubu için akademik başarıda bir artış olduğunu göstermektedir.Burada kullanılan yöntemlere bakılmaksızın, öğrenmenin gerçekleştiği görülmektedir.Ancak, işbirlikli öğrenme yönteminin uygulandığı deney grubundaki gelişimin daha ileri düzeyde olduğu söylenebilir.

Deney ve kontrol gruplarının sontest puanları arasında anlamlı bir fark olup olmadığını belirlemek için bağımsız gruplar t-testi kullanıldı ve sonuçlar Tablo 5 'te sunuldu.

Tablo 5.

Deney ve Kontrol Gruplarının Son Testlerinin Bağımsız Gruplar T-Testi Analiz Sonuçları.

\begin{tabular}{llccccc}
\hline Testler & Gruplar & $\mathrm{N}$ & $\overline{\mathrm{X}}$ & $\mathrm{SD}$ & $\mathrm{t}$ & $\mathrm{p}$ \\
\hline \multirow{2}{*}{ Sontest } & Deney & 33 & 18.76 & 3.717 & & \\
& & & & & 3.388 & 0.001 \\
& Kontrol & 22 & 15.41 & 3.390 & & \\
\hline
\end{tabular}

Tablo 5 'te, işbirlikli öğrenme yöntemiyle bilgisayar okuryazarlık dersini izleyen deney grubunun son test ortalama puanının ( $\bar{X}=18.76$ ), geleneksel yöntem ve tekniklerle takip eden control grubunun son test ortalama puanından ( $\overline{\mathrm{X}}=15.41$ ) daha yüksek olduğu görülmektedir. Yapılan t-testi sonucunda deney ve kontrol grubunun son test puan ortalamaları arasında deney grubu lehine anlamlı bir fark olduğu görülmektedir ( $p$ <.05).Ayrıca bu sonuçlardan da görüleceği gibi, öğrenciler birlikte çalışırken daha başarılı olmaktadırlar. Kısacası, bilgisayar okuryazarlığı dersinde işbirlikli öğrenme yönteminin geleneksel yöntemden daha etkili olduğu sonucuna varılabilir.

Deney ve kontrol grubunun sontest-kalıcılık testi puanları arasında anlamlı bir fark olup olmadığını belirlemek için eşlşi gruplar t-testi kullanılmış ve sonuçlar Tablo 6 ve Tablo 7'de sunulmuştur.

Tablo 6.

Deney grubu sontest ve kalıcılık eşli gruplar t-testi analiz sonuçları.

\begin{tabular}{lcccccc}
\hline Testler & Gruplar & $\mathrm{N}$ & $\mathrm{X}$ & $\mathrm{SD}$ & $\mathrm{t}$ & $\mathrm{p}$ \\
\hline Sontest & & 33 & 18.76 & 3.717 & & \\
& Deneyl & & & & 3.514 & 0.110 \\
Kalıcilık & & 33 & 17.76 & 2.905 & & \\
\hline
\end{tabular}

Tablo 6 incelendiğinde, bilgisayar destekli işbirlikli öğrenme yöntemi ile öğrenen deney grubunun son test ortalama puanı ( $\overline{\mathrm{X}}=18,76)$ ile kalıcılık testi ortalama puanı $(\overline{\mathrm{X}}=17,76)$ arasında anlamlı bir fark olmadığı görülmektedir ( $p>0.05$ ). Bu nedenle, işbirlikli öğrenme metodu jigsaw tekniği kullanıldığında öğrenenilenlerin kalıcı olduğu söylenebilir.

Tablo 7.

Kontrol grubu sontest ve kalıcılık eşli gruplar t-testi analiz sonuçları.

\begin{tabular}{llccccc}
\hline Tester & Gruplar & $\mathrm{N}$ & $\overline{\mathbf{X}}$ & $\mathrm{SD}$ & $\mathrm{t}$ & $\mathrm{p}$ \\
\hline Sontest & & 22 & 15.41 & 3.390 & & \\
& Kontrol & 22 & 15.05 & 4.766 & & 0.310 \\
Kalıcılık & & 22 & & & \\
\hline
\end{tabular}

Tablo 7 incelendiğinde, geleneksel olarak bilgisayar okuryazarlığı dersi alan kontrol grubunun sontest ortalama puanı $(\overline{\mathrm{X}}=15.41)$ ve kalıcılık testi ortalama puanı $(\overline{\mathrm{X}}=15.05)$ arasında anlamlı bir fark olmadığ 
Tekdal \& Sönmez - Çukurova Üniversitesi Eğitim Fakültesi Dergisi, 47(1), 2018, 37-59

görülmektedir ( $p>0,05)$. Böylece, geleneksel öğrenme yönteminde de öğrenilenlerinkalıcı olduğu söylenebilir.

Tablo 8, deney ve kontrol gruplarının kalıclık testi puanları arasında anlamlı bir fark olup olmadığını belirlemek için yapılan bağımsız grup t testi analizi sonuçlarını göstermektedir.

Table 8.

Deney ve Kontrol Gruplarının KalıcılıkTestlerinin Bağımsız Gruplar T-Testi Analiz Sonuçları.

\begin{tabular}{llccccc}
\hline Testler & Groups & $\mathrm{N}$ & $\overline{\mathbf{X}}$ & $\mathrm{SD}$ & $\mathrm{t}$ & $\mathrm{p}$ \\
\hline \multirow{2}{*}{ Kalıcilık } & Deney & 33 & 17.76 & 2.905 & & \\
& & & & & 2.625 & 0.011 \\
& Kontrol & 22 & 15.05 & 4.766 & & \\
\hline
\end{tabular}

Tablo 8 incelendiğinde, deney grubunun $(X=17,76)$ kalıcılık testinin ortalama puanının kontrol grubunun ( $X=15.05$ ) ortalama puanından daha yüksek olduğu görülmektedir. Bu nedenle deney ve kontrol gruplarının kalıcılık testi puanları arasında deney grubu lehine anlamlı bir fark olduğu söylenebilir ( $p<0.05)$. Sonuç olarak; Öğrencilerin bilgisayar okuryazarlığı dersinde öğrenilenlerin kalıcılığı açısından işbirlikli öğrenme yönteminin geleneksel yöntemden daha etkili olduğu söylenebilir.

\section{Sonuçlar ve Tartışma}

Bu araştırmada işbirliğine dayalı öğrenme yöntemi, birleştirme tekniği ile bilgisayar okur-yazarlığı öğretiminin akademik başarıya ve öğrenilenlerin kalıcılı̆̆ına etkisinin olup olmadığı ve işbirliğine dayalı öğrenme yöntemi ile geleneksel yöntem arasında, akademik başarı ve öğrenilenlerin kalıcılığı açısından anlamlı bir fark olup olmadığı incelenmiştir.

Çalışma, deney ve kontrol grubu olmak üzere iki grup ile yürütülmüştür.Araştırmanın deney grubu 33, kontrol grubu 22 olmak üzere toplam 55 tane ilköğretim öğrencisinden oluşmaktadır.Deney ve control grubunun ön test puanları arasındaki farkın anlamlılığı incelenmiş ve anlamlı bir farklılık bulunmamıştır.Başlangıçta her iki grubun Bilgisayar Okuryazarlığı dersi başarısı açısından eşit olduğu belirlenmiştir.Her iki gruba uygulamadan sonra sontest uygulandı ve deney grubunun kontrol grubundan daha başarılı olduğu bulundu.Bu nedenle, bilgisayar okuryazarlığının işbirlikli öğrenme yöntemi birleştirme tekniği ile öğrenilmesinin geleneksel öğrenme yönteminden daha etkili olduğu sonucuna varılabilir.Son olarak, çalışmadan üç hafta sonra, deney ve kontrol gruplarına aynı test uygulanmış ve öğrencilerin öğrenilenleri ne oranda hatırladıkları saptamış ve hem deney hem de kontrol gruplarınınkalıcılık puanları ile son test puanları arasında anlamlı bir fark bulunmamıştır.Başka bir deyişle, öğrencilerin uygulanan öğrenme metodundan bağımsız olarak öğrendiklerini hatırlayabildiği sonucuna varabiliriz.

Bu araştırmanın sonuçlarına dayanarak, Jigsaw işbirlikli öğrenme yöntemi, birleştirme tekniğinin Bilgisayar Okuryazarlığı sınıfı için etkili bir öğretim yöntemi olduğu sonucuna varılabilir.Bu sonuç, aktif öğrenme ortamlarında takımlarla çalışma ve diğer öğrencilerle işbirliği yapma gibi bu işbirlikli öğrenme tekniğinin özelliklerinden kaynaklanabilir.

Yine de, bilgisayar okuryazarlığı öğretirken işbirlikli öğretme yönteminin geleneksel yöntemlere büyük oranda bir üstünlük sağladığını söyleyemeyiz. Çünkü deney ve kontrol gruplarının ön test puan ortalaması sırasıyla 15.12 ve 13.41 idi.Bu puanlar son test puanları ile karşılaştırıldığında, deney grubunda yaklaşık 3.35 soru ve kontrol grubununda 2 soru artışı olduğu görülmüştür. Bu nedenle, işbirlikli öğretme yöntemi ile öğretim, öğrenciler tarafından sadece 1 ila 1.5 daha fazla soru cevaplamalarına neden olur. Bunun nedeni, öğrencilerin aynı ortamda bulunmaları ve birbirleriyle etkileşim kurmaları olabilir. Ayrıca, öğrenciler arasında bilgisayar derslerinin beğeni ve çekiciliği bu durumun oluşmasında rol oynamış olabilir.

$\mathrm{Bu}$ çalışmanın bulguları, işbirlikli öğrenme tekniklerinin geleneksel öğrenme yöntemlerine göre öğrencilerin başarıları üzerindeki öğrenme etkisinin olumlu bulgularını destekleyen literatürdeki bir 
takım araştırmalarla da uyumludur (Artut ve Tarim, 2007; Berger \& Hänze, 2015; Doymus, 2008; Gömleksiz, 2007; Mari, \& Gumel, 2015; Mengduo, \& Xiaoling, 2010; Olukayode).\& Salako, 2014; Sevim, 2015; Şahin, 2011; Tarhan, Ayyıldız, Ogunc ve Sesen, 2013; Wyk, 2012).Bununla birlikte, işbirlikçi yöntemin geleneksel yöntemden daha az ya da eşit etkiye sahip olduğunu gösteren az sayıdaki çalışma da yayınlanmıştır.Örneğin, Hänze ve Berger (2007), yaptıkları çalışmanın birleştirme tekniğinin akademik performans üzerindeki olumlu etkilerini göstermediğini bildirmişlerdir.Çalışmalarında, 12.sınıf fizik dersindeki öğrenciler geleneksel öğretim yöntemi ile işbirliğine dayanan öğretim yöntemi birleştirme tekniğini karşılaştıran yarı deneysel bir çalışmaya katılmıştır. Her ne kadar, bu karşıt sonuçlar işbirlikli öğrenme literatüründe bir çelişki gibi görünse de, Slavin, Hurley ve Chamberlain (2003), işbirlikli öğrenme üzerine yapılan araştırmanın, eğitim araştırması tarihindeki en büyük başarı öykülerinden biri olduğunu iddia etmektedir.

Şaşırtıcı bir şekilde, kalıcılık testi puanları arasında anlamlı bir fark olmamasına rağmen, deney ve kontrol gruplarının sontest puanları arasında istatistiksel olarak anlamlı bir fark bulunmuştur.Bu, aynı testin hem deney hem de kontrol gruplarına hem bir son test hem de bir kalıcilık testi olarak uygulanmasından kaynaklanabilir.

Bu çalışmanın sonuçlarından yola çıkarak, birleştirme tekniğinin öğrenmeyi geliştirmek ve öğrencilere etkili ve eğlenceli bir öğrenme ortamı sağlamak için etkili bir işbirlikçi öğrenme yöntemi olduğu açıktır. Bu bağlamda, bu çalışmanın bulgularına dayanarak, araştırmacılar şu önerileri sunmak istemektedir: (1) Bu araştırmaya sadece 6 . Sınıf (11-13 yaş) öğrenciler katılmıştır.İşbirlikli öğrenme yöntemiyle bilgisayar okuryazarlığı öğretimi, farklı yaş grubu öğrencilerine uygulanarak yeni araştırmalar yapılabilir, (2) bu araştırmadaki bilgisayar laboratuvarının koşulları çok sınırlıydı.Laboratuarda internet bağlantısı yoktu.Yazıcı ve tarayıcı gibi eksik ekipman vardı. Fiziksel koşullar değiştirildiğinde ve uygulandığında farklı sonuçlar ortaya çıkabilir, (3) Öğrencilerin işbirlikli öğrenme ortamında nasıl bir gruplandırmayı benimsedikleri araştırılabilir. Böylece her öğrenci grup çalışmasından daha fazla yararlanabilir, ve (4) işbirlikli öğrenme yönteminin uygulanmasında, sınıf yönetimi ve grup oluşumunda öğretmenin ne tür sorunlarla karşılaştığı araştırılabilir. 


\section{References}

Alabekee, E. C., Samuel, A., \& Osaat, S. D. (2015).Effect of cooperative learning strategy on students learning experience and achievements in mathematics. International Journal of Education Learning and Development, 3(4), 67-75.

Altun, S. (2015). The Effect of Cooperative Learning on Students' Achievement and Views on the Science and Technology Course. International Electronic Journal of Elementary Education, 7(3), 451.

Apugliese, A., \& Lewis, S. E. (2017).Impact of instructional decisions on the effectiveness of cooperative learning in chemistry through meta-analysis. Chemistry Education Research and Practice, 18(1), 271 278.

Aronson, E. (2002). Building empathy, compassion, and achievement in the jigsaw classroom.Improving academic achievement: Impact of psychological factors on education, 209-225.

Artut, P. D., \& Tarim, K. (2007). The effectiveness of jigsaw II on prospective elementary school teachers.Asia-Pacific Journal of Teacher Education, 35(2), 129-141.

Berger, R., \& Hänze, M. (2015).Impact of expert teaching quality on novice academic performance in the jigsaw cooperative learning method.International Journal of Science Education, 37(2), 294-320.

Capar, G., \& Tarim, K. (2015). Efficacy of the Cooperative Learning Method on Mathematics Achievement and Attitude: A Meta-Analysis Research. Educational Sciences: Theory and Practice, 15(2), 553-559.

Doymus, K. (2008). Teaching chemical bonding through jigsaw cooperative learning. Research in Science \& Technological Education, 26(1), 47-57.

Gambari, I. A., \& Yusuf, M. O. (2016).Effects of Computer-Assisted Jigsaw II Cooperative Learning Strategy on Physics Achievement and Retention. Contemporary Educational Technology, 7(4), 352367.

Gömleksiz, M. N. (2007). Effectiveness of cooperative learning (jigsaw II) method in teaching English as a foreign language to engineering students (Case of Firat University, Turkey).European journal of engineering education, 32(5), 613-625.

Hänze, M., \& Berger, R. (2007). Cooperative learning, motivational effects, and student characteristics: An experimental study comparing cooperative learning and direct instruction in 12th grade physics classes. Learning and instruction, 17(1), 29-41.

Johnson, D. W., \& Johnson, R. T. (1999).Making cooperative learning work. Theory into practice, 38(2), 67-73.

Johnson, D. W., Johnson, R. T., \& Stanne, M. B. (2000). Cooperative Learning Methods: A MetaAnalysis. Retrieved from:https://www.researchgate.net/profile/David_Johnson50/publication/220040324_Cooperative _learning_methods_A_meta-analysis/links/00b4952b39d258145c000000.pdf

Haack, M. P. (2014). The effects of cooperative-learning strategies on students' understanding of high school biology.Master of Science Thesis. Retrieved from: https://scholarworks.montana.edu/xmlui/bitstream/handle/1/3554/HaackM0814.pdf?sequence=1

Holubec, E., Johnson, D. W., \& Johnson, R. T. (1993).Impact of cooperative learning on naval air traffic controller training. The Journal of Social Psychology, 133(3), 337-346.

Keser, H., \& Teker, N. (2011). The Study of Developments in Computer Education in Turkey between 1960-1988. Elementary Education Online, 10(3), 1010-1027.

Küçükahmet, L. (1997). Eğitim programları ve öğretim.Ankara: Gazi Kitabevi.

Lazarowitz, R. (1995). Learning science in cooperative modes in junior and senior high schools: Cognitive and affective outcomes.Secondary schools and cooperative learning: Theories, models, and strategies, 185-227.

Mari, J. S., \& Gumel, S. A. (2015). Effects of jigsaw model of cooperative learning on self-efficacy and achievement in chemistry among concrete and formal reasoners in colleges of education in Nigeria. International Journal of Information and Education Technology, 5(3), 196.

Mengduo, Q., \& Xiaoling, J. (2010). Jigsaw Strategy as a Cooperative Learning Technique: Focusing on the Language Learners. Chinese Journal of Applied Linguistics (Foreign Language Teaching \& Research Press), 33(4). 
Tekdal \& Sönmez - Çukurova Üniversitesi Eğitim Fakültesi Dergisi, 47(1), 2018, 37-59

Olukayode, A. S., \& Salako, E. T. (2014).Effect of Jigsaw Technique and Gender on Students' Attitude to Ethnic Integration and Sustainable Development in Nigeria. World Journal of Education, 4(3), 46.

Orhan, F. (1995).Bilgisayar Ders Yazılımlarının Değerlendirilmesi İçin Bir Model Önerisi. Yayımlanmamış doktora tezi, Hacettepe Üniversitesi Sosyal Bilimler Enstitüsü, Ankara.

Othman, M., Hussain, F. M., \& Nikman, K. (2017).Enhancing logical thinking among computer science students through cooperative learning. Gading Journal for the Social Sciences, 14(01).

Sevim, O. (2015). Influence of the Subject Jigsaw Technique on Elementary School Seventh Grade Students' Academic Achievement and On Their Problem Solving Skills.Egitim ve Bilim, 40(177).

Slavin, R. E. (1987). Developmental and motivational perspectives on cooperative learning: A reconciliation. Child development, 1161-1167.

Slavin, R. E., Hurley, E. A., \& Chamberlain, A. (2003). Cooperative learning and achievement: Theory and research. Handbook of psychology.

Steiner, S., Stromwall, L. K., Brzuzy, S., \& Gerdes, K. (1999). Using cooperative learning strategies in social work education.Journal of Social Work Education, 35(2), 253-264.

Şahin, A. (2011).Effects of Jigsaw III technique on achievement in written expression.Asia Pacific Education Review, 12(3), 427-435.

Tarhan, L., Ayyıldız, Y., Ogunc, A., \& Sesen, B. A. (2013). A jigsaw cooperative learning application in elementary science and technology lessons: physical and chemical changes. Research in Science \& Technological Education, 31(2), 184-203.

Warfa, A. R. M. (2015). Using cooperative learning to teach chemistry: A meta-analytic review. Journal of Chemical Education, 93(2), 248-255.

Wyk, M. M. V. (2012). The effects of the STAD-cooperative learning method on student achievement, attitude and motivation in economics education.Journal of Social Sciences, 33(2), 261-270.

Yang, A.,\& Cheung, C. P. (2003). Adapting textbook activities for communicative teaching and cooperative learning. In English Teaching Forum, 41(3), 16-20. 